\title{
PARÁMETROS DE INTERÉS NUTRICIONAL EN SEMI- LLAS DE VINAL (Prosopis ruscifolia)
}

\author{
Freyre, M. R. ${ }^{1}$; Bernardi, C. M. H. ${ }^{1}$; BAIGORRIA, C. M. ${ }^{1}$; ROZYCKI, V. R. ${ }^{1}$; \\ Piagentini, A. M. ${ }^{1}$; Presa, M. $^{2}$ \& Thater, H. A. ${ }^{2}$
}

\begin{abstract}
RESUMEN
Se estudió la presencia de distintos nutrientes en las semillas de Prosopis ruscifolia (vinal), leguminosa arbórea silvestre ampliamente difundida en el Noreste argentino. Se informa la composición centesimal; el perfil de aminoácidos y de ácidos grasos, minerales tales como calcio, fósforo, potasio, magnesio, hierro y zinc, a la par que se investigan la presencia de sustancias con actividad antinutricional, como inhibidores de tripsina, polifenoles y fitatos.

El análisis de la información generada en este trabajo indica que son ricas en proteínas (354,8 g/ $\mathrm{kg}$ ) presentando importantes valores del aminoácido lisina, así como poseen un importante nivel de fibra dietaria $(548 \mathrm{~g} / \mathrm{kg}$ ) constituída mayoritariamente por galactomananos, el contenido lipídico aproximado a $50 \mathrm{~g} / \mathrm{kg}$ está caracterizado por una importante insaturación con predominio de ácido linoleico; y aportan buenos niveles de hierro $(49,3 \mu \mathrm{g} / \mathrm{g})$ y otros micronutrientes. Los niveles de antinutrientes hallados en este estudio son semejantes a otros Prosopis, o mejor aún resultan inferiores a otras leguminosas. Estudios relativos a otros aspectos nutricionales, tecnológicos y propiedades funcionales de este recurso serán reportados en próximas comunicaciones de este grupo de investigación.

Palabras claves: vinal, Prosopis, nutrientes, composición, semillas.
\end{abstract}

\section{SUMMARY}

\section{Nutritionally important parameters from vinal (Prosopis ruscifolia) seeds.}

This work is aimed to asses the composition of Prosopis ruscifolia seeds related to its nutritional aspects in order to evaluate its potential as a food ingredient. In this study the proximal composition; the aminoacids and fatty acids profiles and the mineral content with emphasis upon micronutrients are reported. Besides, antinutritional factors such as proteinase inhibitors, polyphenols and phytates are studied. The most remarkable results show that they are rich in proteins $(354,8 \mathrm{~g} / \mathrm{kg})$ where a high level of lysine is found; a very good source of dietary fiber made up mostly by galactomannans ( 548 $\mathrm{g} / \mathrm{kg}$ ), low content of lipids (around $50 \mathrm{~g} / \mathrm{kg}$ ) although highly unsaturated and dominated by linoleic acid; provide a good source of iron $(49,3 \mu \mathrm{g} / \mathrm{g})$ and other micronutrients. The antinutritional contents found here showed equivalent levels to other Prosopis or lower than other leguminous seeds. Further studies devoted to other nutritional, technological features and functional properties are currently under development and will be published elsewhere by this research group.

Key words: vinal, Prosopis, nutrients, composition, seeds.

1.- Instituto de Tecnología de Alimentos, Facultad de Ingeniería Química (UNL). $1^{\circ}$ de Mayo 3250. (3000)

Santa Fe. Email: cbernard@fiq.unl.edu.ar

2.- Facultad de Bioquímica y Ciencias Biológicas (UNL).

Manuscrito recibido el 15 de marzo de 2010 y aceptado para su publicación el $1^{\circ}$ de junio de 2010 . 